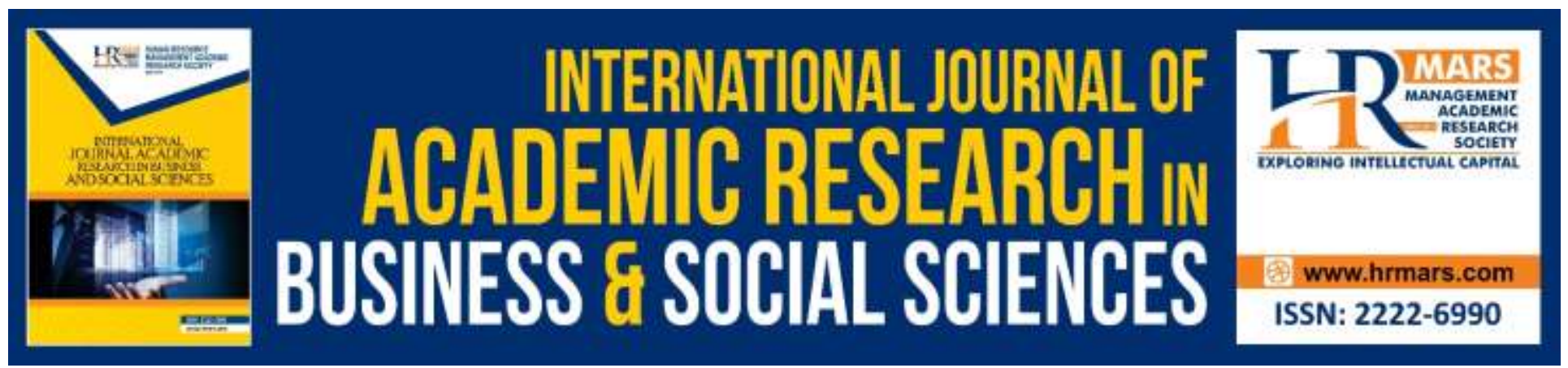

\title{
Teachers Motivation Towards Job Performance Appraisal Among Secondary School Teachers
}

Noor Fadzliana Ahmad Jaafar \& Syed Sofian Syed Salim

To Link this Article: http://dx.doi.org/10.6007/IJARBSS/v9-i7/6155

DOI: $10.6007 /$ IJARBSS/v9-i7/6155

Received: 12 May 2019, Revised: 14 June 2019, Accepted: 29 June 2019

Published Online: 13 July 2019

In-Text Citation: (Jaafar \& Salim, 2017)

To Cite this Article: Jaafar, N. F. A., \& Salim, S. S. S. (2017). Teachers Motivation Towards Job Performance Appraisal Among Secondary School Teachers. International Journal of Academic Research in Business and Social Sciences, 9(7), 646-653.

Copyright: (C) 2019 The Author(s)

Published by Human Resource Management Academic Research Society (www.hrmars.com)

This article is published under the Creative Commons Attribution (CC BY 4.0) license. Anyone may reproduce, distribute, translate and create derivative works of this article (for both commercial and non-commercial purposes), subject to full attribution to the original publication and authors. The full terms of this license may be seen

at: http://creativecommons.org/licences/by/4.0/legalcode

Vol. 9, No. 7, 2019, Pg. 646 - 653

http://hrmars.com/index.php/pages/detail/IJARBSS

JOURNAL HOMEPAGE

Full Terms \& Conditions of access and use can be found at http://hrmars.com/index.php/pages/detail/publication-ethics 


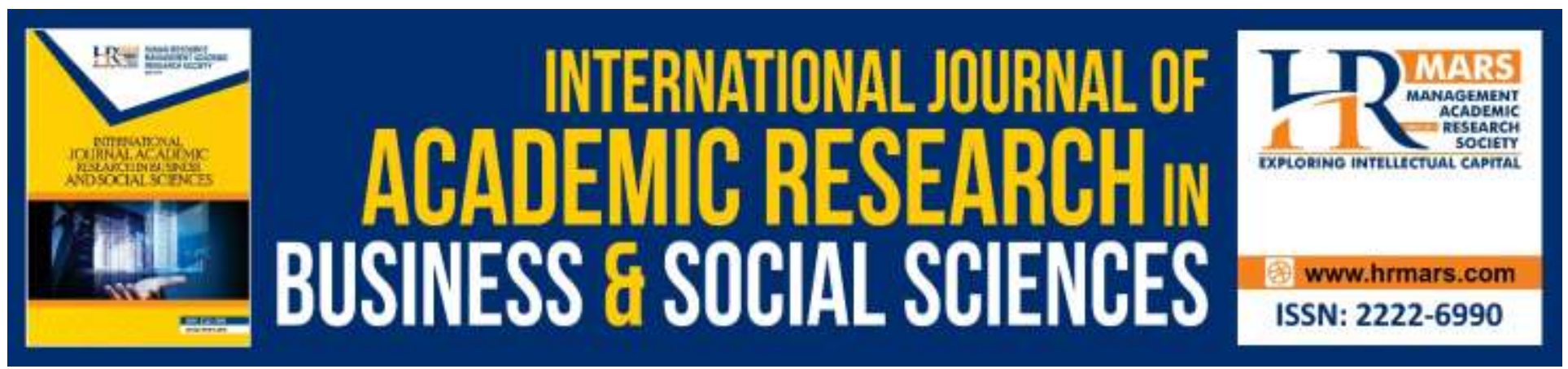

\title{
Teachers Motivation Towards Job Performance Appraisal Among Secondary School Teachers
}

\author{
Noor Fadzliana Ahmad Jaafar \& Syed Sofian Syed Salim \\ Faculty of Education and Human Development, Sultan Idris Education University, Tanjong Malim, \\ Perak, Malaysia
}

\begin{abstract}
The aim of this study is to examine the relation between performance appraisal and motivation of teachers. For this purpose, data was collected from 297 teachers from seven schools in the district of Sabak Bernam. The performance appraisal scale and the motivation scale were used. According to the first finding obtained, while the motivation and performance appraisal beliefs did not differentiate according to sex. Second, significant relations in positive terms were obtained between aspects of performance appraisal and motivation of teachers. Lastly, employee skills assessment is the most dominant aspects affect the effectiveness of the performance evaluation.
\end{abstract}

Keywords: Motivation, Performance Appraisal, School and Teachers

\section{Introduction}

The Integrated Assessment for Education Service Officer (PBPPPP) been approved to replace the once-a-year Laporan Prestasi Tahunan (LNPT). Implementation PBPPP to replace LNPT to all education service officers (PPP) was started in January 2016. The implementation of PBPPP is required in promotion and career development.

Performance appraisal is important to organizations and employees to achieve goals, objectives and standards that have been approved. Performance appraisal is the important mechanisms for the excellence of the organization to ensure effective implementation, performance evaluation should be planned, controlled and managed effectively. The implementation of performance evaluation should be done as accurately as possible because it will affect the assessment in decision-making related to the promotion, determination of training, exchange and movement of workers' salary ( $A b$, 2012).

Motivation and work performance will be given attention which focus on the discussion of the organization. This is due to a combination of motivation and work performance can create harmony and complement to each other. The effectiveness of the individual can be achieved if employees can be motivated. The successful management of organizational alignment of interests with the interests of the individual depends on the success motivate employees to produce the desired results (Mahaliza, 2004). 


\section{Literature Review}

\section{(a) Motivation}

The word 'motivation' comes from the Latin word 'mover' which means 'to move'. Motivation is a continuous process in doing a job. It happened not even occur spontaneously only by psychiatric driven by various internal and external factors that are often variable. Motivation is a desire to do something comprehensive. It occurs due to physiological and psychological tension towards an objective to be achieved. Stimulus and environmental influences may reinforce the degree of one's desire to do something in earnest. Satisfaction is achieved by a person normally would be a reinforcement and stiffening him (Mohamed, 2011).

The power of motivation depends on:

i) The natural tension in a situation and urgent to address it.

ii) The bitter experience or disappointment suffered by any person to persuade him to restore the feeling of normalcy.

iii) The goal of interests such as bonuses or attractive salary in a career field that will be involved.

iv) Encouragement and moral support from significant people in one's life.

A study was conducted in three Special Primary Schools in Selangor and Kuala Lumpur by Mohamed (2011). The findings by $t$ test showed that there were significant differences of motivation between male and female teachers. While based on a study conducted by the Bambang (2016) and Nurul (2013) found no significant differences between female teachers.

Purnama (2012) in his study of motivation Relationship With Job Performance of Teachers And Employees At SMK Muhammadiyah 1 Yogyakarta found that the level of motivation of teachers and employees of SMK Muhammadiyah 1 Yogyakarta is in the high category. Meanwhile, a study conducted by Triyanto and Rif'ati (2016) have found that there is significant difference between teachers of male teachers has motivation levels higher than female teachers.

Spear, Gould and Lee (2000) in his study of what motivates and does not motivate teachers:

1. high career satisfaction

2. Work-provoking

3. Autonomy

4. work that benefits the community

5. good relationships with colleagues

6. the division of labor a good time

7. Increased salaries

8. Improving the status

9. low workload

10. Less administrative responsibility

\section{(b). Work Performance Appraisal}

Performance appraisal of employee performance is done regularly and compared with the targets set. From the results of the assessment, managers can identify the potential of the employees to enable them to draw up progress and development program (Azizi, 2014).

Performance appraisal is a process analysis carried out continuously to see the contributions made by the employee. Throughout the evaluation process takes place, the individual will be 
assessed, recorded, reported, discussed and followed up with the aim of improving the quality or quantity of work performed (Ab, 2014).

Muhammad et al. (2014) conducted a survey of 200 teachers (100 males and 100 female teachers) in secondary schools in Punjab, Pakistan. The results of the t-test showed that there were significant differences between male and female teachers gender on performance appraisal system.

Abdull, Ab, Tang and Lim (2008) through his study found that teachers' perception of the two dimensions of performance appraisal justice and procedural fairness of distributive justice is not so encouraging. This means that most of the teachers thought justice in performance appraisal system in their workplace is simple.

Devi (2006) through his research findings show that there is no difference between sex for the purpose of performance appraisal and acceptance Competency Assessment. The study also found a significant correlation exists between employee attitudes and skills assessment with the purpose and effect of acceptance of appraisals. While the relationship between performance appraisal techniques for the purpose is insignificant. But a valuation technique significantly correlated with performance appraisal of the effects.

\section{Methodology}

The sample included in this study was 297 teachers from seven secondary school in the district of Sabak Bernam. Purposive sampling method used to obtain the data. A questionnaire was used which consists of three sections: A, demographic factors, and part B, item-item questionnaire was based on performance evaluation questionnaires used by Devi (2006). As for section C, based on a questionnaire Mohammad et al. (2015). Parts B and C using a Likert scale. All data were analyzed using the "Statistical Package for Social Sciences" (SPSSV. 22 for Windows). Pearson (The Pearson's Correlation Matrix) and independent $t$ test was used to analyze the data.

\section{Findings}

The teachers involved in this study were 297 people. 121 respondents were from male teachers (40.7\%) while 176 respondents was comprised of female teachers $(59.3 \%)$. This shows that the number of respondents were female teachers outnumber male teachers

\section{(a). Differences gender and teacher motivation}

Independent samples t-test was performed to compare the differences between male and female teachers with motivation. There was no significant difference in the scores of male teachers (mean $=$ $3.73, \mathrm{sd}=0.3$ ) with women teachers (mean $=3.73, \mathrm{sd}=0.4 ; \mathrm{t}(\mathrm{df}), \mathrm{p}(</>)-0.60(295) \mathrm{P}>0.05$.

Table 1: Gender and teacher motivation

\begin{tabular}{llcccc}
\hline Variables & Gender & Mean & s.p & $T$ & Sig. \\
\hline Motivation & Male & 3.73 & 0.3 & -0.60 & 0.953 \\
Teachers & Female & 3.73 & 0.4 & & \\
\hline
\end{tabular}


INTERNATIONAL JOURNAL OF ACADEMIC RESEARCH IN BUSINESS AND SOCIAL SCIENCES

Vol. 9, No. 7, July, 2019, E-ISSN: 2222-6990 @ 2019 HRMARS

(b). Differences Gender and Aspects of performance Appraisal

Independent sample $t$ test was performed to compare the differences between male and female teachers with work performance evaluation. There was no significant difference in the scores of male teachers $($ mean $=3.72, \mathrm{sd}=0.4)$ with women teachers (mean $=3.67, \mathrm{sd}=0.4 ; \mathrm{t}(\mathrm{df}), \mathrm{p}(</>) 0865$ (295), $\mathrm{P}>0.05$.

Table 2: Gender and aspects of performance appraisal

\begin{tabular}{llllll}
\hline Variables & Gender & Mean & s.p & $T$ & Sig. \\
\hline Performance & Male & 3.72 & 0.4 & 0.865 & 0.388 \\
appraisal & Female & 3.67 & 0.4 & & \\
\hline
\end{tabular}

(c). Relationship Aspect Performance appraisal With Teacher Motivation

Pearson correlation analysis results showed aspects of performance appraisal has a simple relationship with the motivation of teachers and found that the value of the correlation coefficient is $r=0.539$. This proves that there exists a positive correlation with the level of medium relationships between aspects of performance appraisal and motivation of teachers. It means that the null hypothesis is rejected at significant level of 0.01 and the alternative hypothesis is accepted that there is a significant relationship between aspects of performance appraisal and motivation of teachers.

Table 3: Relationship aspect of performance appraisal with teacher motivation

\begin{tabular}{lccc}
\hline Variables & $\begin{array}{c}\text { Pearson } \\
\text { correlation }(r)\end{array}$ & Sig. & Relationship \\
\hline $\begin{array}{l}\text { Aspect Performance appraisal } \\
\text { With Teacher Motivation }\end{array}$ & $0.539 * * *$ & 0.000 & Medium \\
\hline
\end{tabular}

(d). The most dominant factor influencing the effectiveness of the performance evaluation According to respondents, the most dominant are the skills of officers (Mean $=4.0825, S D=0.62865$ ), technique of PBPPP (Mean $=3.8258$, SD $=0.91611$ ), impact of PBPPP (Mean = 3.7685, SD = 0.74127), PBPPP (Mean $=3.7685$, SD $=0.74127)$, goal of PBPPP $($ Mean $=3.5581$, SD $=0.64150)$ and the attitude of the first and second officers (Mean $=3.3645, S D=0.65239$ ).

Table 4: The most dominant factor influencing the effectiveness of the performance appraisal

\begin{tabular}{llcc}
\hline Bil & Performance appraisal & Mean & SD \\
\hline 1. & Skill of the officers & 4.0825 & 0.62865 \\
2. & Technique of PBPPP & 3.8258 & 0.91611 \\
3. & impact PBPPP & 3.7685 & 0.74127 \\
4. & PBPPP & 3.5867 & 0.50447 \\
5. & Goal of PBPPP & 3.5581 & 0.64150 \\
6. & Attitude of the first and second officers & 3.3645 & 0.65239 \\
\hline
\end{tabular}


INTERNATIONAL JOURNAL OF ACADEMIC RESEARCH IN BUSINESS AND SOCIAL SCIENCES Vol. 9, No. 7, July, 2019, E-ISSN: 2222-6990 @ 2019 HRMARS

\section{Discussion}

According to the first finding of the research, the results showed that gender male and female teachers gave no difference to the motivation of teachers. This finding is supported by research conducted by Spear et al. (2000), and Bambang (2016). Teachers have high motivation when teachers feel great satisfaction in a career, relationship with colleagues, salary increases, work that challenges the mind, less administrative responsibility, improve the status and low workload. It shows teachers motivations male and female teachers are in high level. Based on the above findings, the researchers can conclude that the presence of stimulating factors in the workplace will be able to produce and increase the motivation to teachers regardless of gender.

While the aspects of performance appraisal do not differ significantly based on gender. This shows that the acceptance of appraisals are in a high level. This finding was also supported by Muhammad et al. (2014) showed that there were significant differences between male and female teachers gender on performance appraisal system. Suhaimi (2011) pointed out that justice is a key element in the performance evaluation that will determine the success and acceptance by employees, which ultimately will ensure organizations achieve their goals. Justice in the assessment is one of the success factors aspects of performance appraisal received by male and female teachers. Justice in the performance aspect of performance evaluation influences reward and recognition in the teaching profession. The findings show fairness in the implementation of performance appraisal can contribute to the organization of education in improving organizational commitment among teachers. So with this it is important that the implementation of performance evaluation conducted fairly. We can conclude here that the performance appraisal can be received regardless of gender as performance appraisal assessed in a fair and equitable employee will be able to produce committed in the conduct of their work.

A medium relation was found in this study between aspects of performance appraisal and motivation of teachers. This study clearly shows that the hypothesis is rejected. The results show that the performance evaluation seeks to encourage the motivation of teachers to the school organization. This is consistent with studies conducted by Abdul and Christina (2014), which showed a significant relationship between performance evaluation and motivation of teachers. This can also be attributed to the presence of the pull factors at work such as the work itself, achievement, recognition, responsibility and interpersonal relationships will be able to produce and increase the motivation to teachers. Performance appraisal and motivation of teachers are very important because it has a direct effect on job performance and contribution towards the organization (school). This indicates that the performance evaluation may motivate teachers and increase achievement motivation when teachers work directly also will continue to rise this finding is consistent with the government's efforts to intensify the reform and transformation in the field of education in our country.

Lastly, the most dominant factor is the choice of the respondent is an employee skills assessment Respondents believe that officers have strongly competence level to implement an effective performance evaluation. Aspects of competence in question is in terms of knowledge, skills, expertise, experience, attitude and positive nature of its connection with matters relating to the performance evaluation. In addition, employees clearly understand the performance appraisal in terms of philosophy, goals and objectives precisely. This is because the average employee 
performance appraisal has considerable training and extensive exposure to enable them to discharge their duties effectively (Rusli, Azman \& Wan, 2007). This was followed by PBPPP techniques. At the national school performance assessment system implemented annually for teachers grade DGA 29 and 32. The third place followed by PBPPP effect. Integrated Assessment for Educational Services Officer may have an impact on teachers, especially in terms of producing and encouraging new ideas among teachers, can improve the quality of teachers, creating competence and improve teamwork. Followed by PBPPP, performance appraisal system is to allow the performance of officials is assessed in a more systematic and objective. In addition, performance appraisals are also used in a variety of human resource management functions such as career advancement, salary movement, giving intensive, placement and training. Followed by PBPPP purposes. PBPPP used for advice and counseling, teacher training programs, for the purpose of new settlements and also used for Excellent Service Awards to teachers who have given outstanding service based on annual performance. Finally followed by the attitude of the first and second officers. The results showed that the first and second officers to discuss with the officials assessed. The respondents are not satisfied with the way ratings are used as a form of favoritism among employees appraisers with officials assessed, and they said the ratings are influenced by last year's performance. However, there are still the first and second officers who are generous throughout the evaluation period lasts.

\section{Summary}

This study has many limitations. For one, the study is limited by being restricted to the Sabak Bernam centre, which limits the generalizability of the study's findings. In addition, there are many other variables related to motivation that could possibly have an effect on performance appraisal. This study limited itself to only a few selected variables.

\section{Acknowledgement}

This study is a result of a Master Paper project study conducted by Noor Fadzliana Ahmad Jaafar with full cooperation from 297 teachers from seven schools in the district of Sabak Bernam, Selangor, Malaysia.

\section{Corresponding Author}

Name : $\quad$ Associate Professor Dr Syed Sofian Syed Salim

Affiliation: Sultan Idris Education University

Country: Malaysia

Email ID : $\quad$ sofian@fpm.upsi.edu.my

Address : $\quad$ Faculty of Education and Human Development, Sultan Idris Education University 35900 Tanjong Malim, Perak

\section{References}

Ab, A. Y. (2012). Organizational Dilemma Performance Evaluation. Kuala Lumpur: Pearson Malaysia Sdn. Bhd.

Ab, A. Y. (2014). Theory of Human Resource Theory and Implementation. Kuala Lumpur: Dewan Bahasa Dan Pustaka. 
INTERNATIONAL JOURNAL OF ACADEMIC RESEARCH IN BUSINESS AND SOCIAL SCIENCES

Vol. 9, No. 7, July, 2019, E-ISSN: 2222-6990 @ 2019 HRMARS

Abdul, S. A., \& Christina, A. (2014). Perceptions of Performance Assessment, Commitment and Motivation of Technical Secondary School Teachers in Sabah. Sains Humanika, 2 (1), 171-178.

Abdull, S. S., Ab, A. Y., Tang, S. M., \& Lim, K. T. (2008). Fairness in Performance Evaluation Within Teachers and Their Relationships with School Motivation and Academic Performance. International Journal of Management Studies, 15, 159-176.

Bambang, B. W. (2016). Comparation Of Teachers Work Motivation Based On Gender, Age, Education Level, Work Duration, Rank, And School Level. Journal of Education and Social Sciences, Vol. 3, 61-66.

Devi, M. (2006). Acceptance Assessment of Malaysian Remuneration System Performance Among Teachers S.M.K Batang Padang District Perak. Masters Theses. Sultan Idris Education University, Tanjong Malim, Perak, Malaysia.

Mahaliza, M. (2004). Performance Evaluation and Relation to Employment Satisfaction Among Teachers in Batang Padang District, Perak. Masters Theses. Sultan Idris Education University, Tanjong Malim, Perak, Malaysia.

Mohamed, F.Y. (2011). Motivation of Teachers' Work at Three Fruits of Special Education National Schools. Unpublised Manuscript, Research University Grant. Sultan Idris Education

University, Tanjong Malim, Perak, Malaysia.

Mohammad, A. S. M. A., Samsiah, M. J., Syed, S. S. S., Muhammad, B. M., Jaya, N. T., \& Tan, E. S. (2015). Construction, Validity and Reliability of Herzberg Job Satisfaction Inventory. Jurnal Bitara Edisi Khas (Psikologi Kaunseling).Vol.8.

Muhammad, N., Muhammad, T., Muhammad, N. S., \& Mukhtar, A. (2014). Performance Appraisal System: A Gender Based Comparison of Secondary School Teachers in Pakistan. Journal of Basic and Applied Scientific Research, 4(11), 1-6.

Nurul, J. (2013). Influence of Principal Leadership Style on the Motivation Level of Secondary School Teachers in Segamat Johor Baharu. Masters Theses. University of Technology Malaysia, Johor Baharu, Malaysia.

Purnama, S. (2012). Relationship of Work Motivation with Teacher and Employee Performance at SMK Muhammadiyah 1 Sleman. Ph.D Dissertation. Universitas Negeri Yogyakarta, Indonesia.

Rusli, A., Azman, I., \& Wan, K. W. I. (2007). Public Sector Performance Evaluation System in Malaysia: Reflections on the Role and Responsibility of Performance Appraisal Officers Jurnal Kemanusiaan, 10.

Spear, M., Gould, K., \& Lee, B. (2000). Who would be a teacher? A review of factors motivating and demotivating prospective and practicing teachers. Slough: NFER.

Suhaimi, S. (2011). Fairness of and satisfaction with performance appraisal process. Journal of Global Management, 2(1), 66-83.

Triyanto., \& Rif'ati, D. H. (2016). Teacher Motivation Based on Gender, Tenure and Level of Education. Journal Stanisław Juszczy, 199-207. 